\title{
Water hyacinth (Eichhornia crassipes) leaves enhances disease resistance in Channa punctata from Vibrio harveyi infection
}

\author{
Vipin Kumar Verma ${ }^{1,2,3^{*}+}$ (D) Om Prakash $^{2 \dagger}$, R. Shiva Raj Kumar ${ }^{2}$, Kumari Vandana Rani ${ }^{4}$ and Neeta Sehgal ${ }^{3}$
}

\begin{abstract}
Background: Channa punctata, Indian spotted snakehead, has a great economic value in south and south-east Asia being an important protein source for humans. Fish cultures are affected due to various bacterial and viral infections. Vibrio harveyi is a fish pathogenic bacteria which causes several outbreaks throughout the world and leads to huge mortalities. In this study, leaves of Eichhornia crassipes (water hyacinth) were used to investigate its immunostimulatory potential in Channa punctata.

Results: The immunostimulatory effects of water hyacinth leaves were studied in fish fed with $2.5 \%$ and $5 \%$ supplementary feed (experimental groups) in comparison to normal feed (control groups). Gas chromatography mass spectrometry (GC-MS) analysis of E. crassipes methanol extract showed presence of various components which have immunostimulatory, antioxidant, antibacterial, and anti-inflammatory activities. The antibacterial activity, antioxidant potential, and presence of phenol and flavonoids in methanol and ethanol extracts supported its use in fish feed. The healthy acclimatized fish were challenged with $V$. harveyi weekly. Liver function tests, alkaline phosphatase levels, and immunoglobulin content in the experimental groups were improved with respect to those in the positive control group. The spleen and head kidney were obtained at the final day of experiment, and macrophages were isolated; higher percentage of phagocytosis and phagocytic index indicated enhanced cellmediated immune response in fish due to supplemented feed.
\end{abstract}

Conclusion: Plant-infused feed with leaves of E. crassipes can be recommended as a regular feed supplement to enhance fish immunity and disease resistance against the $V$. harveyi infection.

Keywords: Eichhornia crassipes, Antibacterial, Antioxidant, Immunostimulant, GC-MS, Channa punctata fish

\section{Background}

Aquaculture of fin fish, crustaceans, and mollusks is one of the fastest growing areas, where different kinds of marine and freshwater fish have been cultured, resulting in increase in worldwide production of cultured fish every year (Tidwell \& Allan, 2001). Fish in water are continuously exposed to ubiquitous

\footnotetext{
* Correspondence: vipinkumarverma1@gmail.com; vipin_zoology@svc.ac.in ${ }^{+}$Vipin Kumar Verma and Om Prakash contributed equally to this work. 'Department of Pharmacology, All India Institute of Medical Sciences, New Delhi 110029, India

${ }^{2}$ Department of Zoology, Sri Venkateswara College, University of Delhi, Dhaula Kuan, New Delhi 110021, India

Full list of author information is available at the end of the article
}

population of viruses, bacteria, and protozoans, among which few are potentially infectious to fish as well as to humans.

Since ancient time, medicinal system with rich herbal traditions has been used by Chinese, Egyptian, Greek, Indian, Mesopotamian, Roman, and Tibetian populations (Hoareau \& DaSilva, 1992; Meena, Bansal, \& Kumar, 2009). Today around $80 \%$ of the world's population uses traditional medicines as their primary health care service. More than 50,000 of plant species are believed to be used for medicinal purposes worldwide (Gewali, 2008). Presence of various components including secondary metabolites like alkaloids,

\section{Springer Open}


flavonoids, tannins, terpenes, and polyphenols have protective pharmacological targets for the prevention against Alzheimer's disease, cancer, inflammatory pains, malaria, and microbial infections.

Water hyacinth (Eichhornia crassipes) is useful in bioenergy production (Bergier, Salis, Miranda, Ortega, \& Luengo, 2012; Huang, 2015) and waste water treatment (Huang, 2015; Todd \& Josephson, 1996). In addition, it is used as vegetables in many countries due to its high carotene content and the presence of various secondary metabolites like terpenoids and alkaloids (Lalitha, Sripathi, \& Jayanthi, 2012). It also has the potential to absorb various harmful water pollutants like lead, mercury, and other carcinogenic chemicals. Their concentrations could be 10,000 times more than the surrounding water in E. crassipes.

It is a very fast-growing plant, which covers the pond very rapidly and affects the ecology of the pond. A study suggested that ponds with $10-15 \%$ E. crassipes covering had a decreased number of phytoplanktons (due to nutritional competition) and zooplanktons (McVea \& Boyd, 1975) and hence a much lower fish production due to disturbed pond ecology.

Pathogens can enter the fish body through various routes and cause infection. Infection depends directly on the virulence strength and quantity of potential pathogen, host animal health, and environment. The most common concern of a fish culturist is the rapid multiplication of pathogens in host and water bodies which is responsible for fast transfer of infection to other individuals, resulting in uncontrollable mortalities in hatcheries, culturing farms, and natural habitats. This not only results in huge economic loss but also makes fish unfit for human consumption.

Vibrio harveyi is a gram-negative bacteria mainly found in marine environment, but few studies also reveal their presence in freshwater, which causes vacuities, skin ulcer, gastro-enteritis, eye lesions and luminous vibriosis, loss of limb functions, and appendage degradation in many fish including teleost's, mollusks, and crustaceans. $V$. harveyi has been responsible for various disease outbreaks throughout the world and cause economic losses to fish farmers as well as aqua-industries (Chatterjee \& Haldar, 2012; Zhou et al., 2012).

Antibiotics for fish have been developed which are chemotherapeutic agents with fast rate of action (Rodgers \& Furones, 2009). Besides the prevention of animal diseases, this may lead to emergence of antibiotic resistance in bacteria, accumulation of drugs in animals, and low nutritional value which deteriorate food quality and cause consumer refusal (Cabello, 2006; Samanidou \& Evaggelopoulou, 2007).
The present study has been focused to determine the biotic potential and immunomodulatory role of E. crassipes, methanolic extract against Vibrio harveyi in Channa punctata fish fed fishmeal supplemented with $2.5 \%$ and $5 \%$ plant powder.

\section{Methods \\ Preparation of plant extracts}

Healthy leaves from the E. crassipes were collected from their natural habitats and washed thoroughly in running tap water. The leaves were shade dried at room temperature, ground to fine powder, and sieved. Five grams of fine powder was soaked separately in ethanol and methanol. The solutions were stirred overnight on a magnetic stirrer at room temperature. The slurry obtained was then filtered through a Whatman filter paper; filtrates were dried using a rotary evaporator and used for determination of various biological activities and gas chromatography mass spectrometry (GC-MS)/MS analysis.

\section{Determination of antibacterial activity}

Antibacterial activity of ethanol and methanol extracts was determined by disc diffusion assay (DDA) against Vibrio harveyi. Sterilized LB agar plates (1.5\%) were prepared with $2 \% \mathrm{NaCl}$, and bacteria were seeded with a standard inoculum of $1 \times 10^{8}$ cells. Sterile circular paper discs (thickness $2 \mathrm{~mm}$; diameter $6 \mathrm{~mm}$ ) were placed on agar plate and were impregnated with $100 \mu \mathrm{l}$ plant extract prepared at six different concentrations $(200,100$, $50,25,12.5$, and $6.25 \mu \mathrm{g}$ per disc) in $0.2 \%$ dimethyl sulphoxide (DMSO). Ampicillin and ciprofloxacin were used as positive control while DMSO $(0.2 \%)$ was used as a negative control.

\section{Antioxidant assays DPPH (2,2-diphenyl-1-picrylhydrazyl) assay}

Antioxidant property of $E$. crassipes leaf extract was determined using the Brand-Williams, Cuvelier, and Berset (1995) method modified by Miliauskas, Venskutonis, and Van Beek (2004). Ten microliters of freshly prepared methanol sample $(0.5 \mathrm{mg} / \mathrm{ml})$ was added to $300 \mu \mathrm{l}$ of DPPH solution $\left(6 \times 10^{-5} \mathrm{M}\right.$ in methanol $)$ in a 96-well microtiter plate. Mixture was incubated at $37^{\circ} \mathrm{C}$ for 20 min, and absorbance was taken at $515 \mathrm{~nm}$. For control, $10 \mu \mathrm{l}$ of methanol was added to $300 \mu \mathrm{l}$ DPPH solution. Free radical scavenging property of plant extract was calculated as percentage inhibition using the standard formula $\left[\left(A_{\mathrm{B}}-A_{\mathrm{S}}\right) / A_{\mathrm{B}}\right] \times 100$, where $A_{\mathrm{B}}$ is the absorbance of blank and $A_{\mathrm{S}}$ is the absorbance of sample (Sarikurkcu, Ozer, Cakir, Eskici, \& Mete, 2013). The assay was performed similarly for the ethanol extract, with ethanol as the carrier blank control. Serial double dilution of 
ascorbic acid was used as a positive standard (20 to $0.078 \mathrm{mg} / \mathrm{ml}$ ). Samples were run in quadruplicates in this assay.

\section{FRAP (ferric-reducing ability of plasma) assay}

$10 \mu \mathrm{l}$ of respective plant extract solution $(0.5 \mathrm{mg} / \mathrm{ml})$ was mixed with $30 \mu \mathrm{l}$ of distilled water and $300 \mu \mathrm{l}$ of freshly prepared FRAP solution (containing 10 parts of $300 \mathrm{mM}$ acetate buffer (pH 3.6), 1 part of $10 \mathrm{mM}$ TPTZ (2,4,6-tripyridyl-s-triazine) in $40 \mathrm{mM} \mathrm{HCl}$, and 1 part of $20 \mathrm{mM}$ ferric chloride). Samples were incubated at $37^{\circ} \mathrm{C}$ for 30 min. A standard curve was prepared by serial double dilution of ferrous sulphate $(20.0$ to $0.009 \mathrm{mg} / \mathrm{ml}$ ) as substrate. Absorbance was recorded at $593 \mathrm{~nm}$. For negative control, acetate buffer was used instead of a sample.

\section{Estimation of total flavonoids}

Flavonoid content of methanol and ethanol extracts of E. crassipes were estimated using the Dowd method as modified by Arvouet-Grand, Vennat, Pourrat, and Legret (1994). One milliliter of $2 \%$ aluminum tri-chloride solution (prepared in methanol) was mixed with $1 \mathrm{ml}$ of plant extract. After $10 \mathrm{~min}$ of incubation at RT, absorbance was recorded at $415 \mathrm{~nm}$. For control (carrier blanks), $1 \mathrm{ml}$ of sample was replaced by methanol/ethanol solution (Sarikurkcu et al., 2013). Concentrations of flavonoids in extracts were calculated using serial double dilution of quercetin as standard $(8.33-0.032 \mathrm{mg} / \mathrm{ml})$.

\section{Determination of total phenolic content (TPC)}

Phenolic content in methanol and ethanol extracts of E. crassipes leaf were determined according to Djeridane et al. (2006). Thirty microliters of extracts (2 $\mathrm{mg} / \mathrm{ml}$ ) was dissolved in $135 \mu \mathrm{l}$ distilled water and $30 \mu \mathrm{l}$ Folin-Ciocalteu's Phenol reagent (2x). Ninety microliters $\mu \mathrm{l}$ of $2 \%$ sodium carbonate solution was added after $3 \mathrm{~min}$, and the mixture was incubated for $2 \mathrm{~h}$ in the dark at $25^{\circ} \mathrm{C}$ with intermittent shaking. Absorbance was recorded at $760 \mathrm{~nm}$, and a standard curve was obtained using serial double dilutions of Gallic acid (20-0.5 $\mu \mathrm{g} / \mathrm{ml})$ (Sarikurkcu et al., 2013).

\section{Gas chromatography mass spectrophotometry (GC-MS) analysis}

Dried methanol extract of E. crassipes was dissolved in HPLC grade methanol $(1 \mathrm{mg} / \mathrm{ml})$. Samples were filtered through a $0.22-\mu \mathrm{m}$ syringe filter, and GC-MS/ MS analysis was performed at AIRF-JNU, New Delhi, India. One microliter of sample was loaded by an automatic programmed syringe injector in the GC-MS instrument.
GC-MS data was then interpreted using NIST/NIH/ EPA Mass spectral Database with NIST05 (National Institute of Standards and Technology) MS program v.2.0d and WILEY08 libraries. Unknown components were also identified with the help of spectrum in NIST and Wiley libraries according to their retention time. The names, chemical formulas, molecular mass, and structure of identified compounds were determined. Chemical and biological activities of identified compounds were found using the online search portal of Dr. Duke's Phytochemical and Ethnobotanical Databases, NCBI-Pubchem, ChemSpider from Royal Society of Chemistry, and various literatures.

\section{Preparation of fish feeds}

Control fish feed was prepared using fish meal, wheat flour, cod liver oil, vitamins, and mineral premixes mixed at definite proportion (Verma, Rani, Sehgal, \& Prakash, 2012). For experimental feed, dried powder of E. crassipes leaf was added to control feed substituting wheat flour at $2.5 \%$ and $5 \%$ proportions. Feed was prepared manually in the form of fine pellet, air dried and stored in an air tight box to prevent bacterial /fungal growth.

\section{Fish maintenance and experimental setup}

C. punctata weighing approximately $150-155 \mathrm{~g}$ were obtained from the local market New Delhi, India. Fish were placed in 150-L glass tanks, fed on control artificial feed, and acclimatized to laboratory conditions: temperature $25 \pm 1{ }^{\circ} \mathrm{C}$ and alternate light and dark intervals of $12 \mathrm{~h}$ each. Fish were fed daily in the morning and evening with $3 \%$ of their body weight. Water of the aquaria was replaced daily with fresh declorinated water maintained at laboratory condition $\left(25 \pm 1{ }^{\circ} \mathrm{C}\right)$. Healthy acclimatized fish were selected for the study on the basis of their skin luster and absence of body lesions. Fish were divided into four groups: group A (negative control; uninjected group fed on supplemented feed), group B (positive control; group injected with $V$. harveyi and fed on non-supplemented feed), and groups $C$ and $D$ (groups injected with $V$. harveyi and fed on experimental feed formulated with $2.5 \%$ and $5 \%$ supplemented feeds containing E. crassipes leaf powder, respectively). Fish were fed on their respective feed 15 days prior to the first challenge. Each group was further subdivided into 4 subgroups $(1,2,3$ and 4$)$. Prior to challenge with bacteria, blood was collected from each subgroup of fish to obtain nonimmunized serum after anesthesia to fish using 2phenoxyethanol at $1 \mathrm{ml} / \mathrm{L}$ concentration. After blood collection, the fish were immediately transferred to 2 successive baths of declorinated water to make them 
Table 1 Antibacterial activity of ethanol and methanol extracts of E. crassipes against $V$. harveyi

\begin{tabular}{llll}
\hline & Concentration & Methanol & Ethanol \\
\hline Eichhornia crassipes & $20 \mathrm{mg} / \mathrm{ml}$ & $1.23 \pm 0.02^{\mathrm{c}, \mathrm{n}}$ & $0.83 \pm 0.02^{\mathrm{b}, \mathrm{m}}$ \\
& $10 \mathrm{mg} / \mathrm{ml}$ & $0.88 \pm 0.02^{\mathrm{b}, \mathrm{n}}$ & $0.70 \pm 0.03^{\mathrm{b}, \mathrm{m}}$ \\
& $5 \mathrm{mg} / \mathrm{ml}$ & $0.73 \pm 0.02^{\mathrm{a}, \mathrm{n}}$ & $0.63 \pm 0.01^{\mathrm{a}, \mathrm{m}}$ \\
Ampicillin & $10 \mathrm{mg} / \mathrm{ml}$ & $0.60 \pm 0.00$ & $0.60 \pm 0.00$ \\
Ciprofloxacin & $10 \mathrm{mg} / \mathrm{ml}$ & $2.17 \pm 0.04$ & $2.13 \pm 0.03$ \\
DMSO & -- & $0.60 \pm 0.00$ & $0.60 \pm 0.00$
\end{tabular}

Values are represented in mean \pm SEM. Values with different superscripts are significantly different. Values with superscripts " $a$ " to " $c$ " represent differences at various concentrations of the extract, while " $\mathrm{m}$ " and " $\mathrm{n}$ " show difference in activity of ethanol and methanol extracts at respective concentrations

immediate sensitive. The fish were injected with $V$. harveyi $\left(1 \times 10^{7}\right.$ cells $)$ intraperitoneally at day 0 . In successive weeks (days 7, 14, and 21), the blood was collected from one subgroup in each group, and the remaining fish were injected with bacteria. For blood collection, fish were temporary anesthetized with 2phenoxyethanol $(1 \mathrm{ml} / \mathrm{L})$, and the blood was collected from the caudal artery using syringes fitted with 22-gauge needle and euthanized through decapitation. After that the fish were decapitated immediately, and organs like the spleen and kidney were excised and kept at $-20^{\circ} \mathrm{C}$ until use. The blood was allowed to clot at RT for $2 \mathrm{~h}$ and then kept overnight at $4{ }^{\circ} \mathrm{C}$. Serum was separated by centrifugation at $3000 \mathrm{~g}$ for $10 \mathrm{~min}$ and stored at $-20{ }^{\circ} \mathrm{C}$ until use. The dead animals were submitted to the dead animals management authority for autoclaving and proper disposal as per CPCSEA guidelines.

\section{Serum biochemical analysis}

Isolated serum from each fish groups collected at different time intervals was used for determination of AST, ALT, and ALP using respective diagnostic kits in 96-well plates following the kit's manufacturer's instructions discussed by Verma et al. (2012). Total protein in the serum samples was also measured using Lowry's method (Lowry, Rosebrough, Farr, \& Randall, 1951).

\section{Phagocytic assay}

Phagocytes were isolated (Verma et al., 2012; Verma, Rani, Sehgal, \& Prakash, 2015) from the anterior kidney and spleen on day 21 and diluted to density at $5 \times 10^{4}$ cells $/ \mathrm{ml}$. Two hundred microliters of isolated cell suspension was evenly spread over pre-washed glass slides and incubated for $1 \mathrm{~h}$ at $25^{\circ} \mathrm{C}$ in $5 \% \mathrm{CO}_{2}$. Three hundred microliters of heat-killed Saccharomyces cerevisiae cells $(3 \mathrm{mg} / \mathrm{ml})$ was spread over adhered phagocytes after washing with PBS (pH 7.4). Slides were incubated for $1 \mathrm{~h}$ at $25^{\circ} \mathrm{C}$ in $5 \% \mathrm{CO}_{2}$. Slides were then washed with PBS (to remove unbound cells), fixed in methanol, and stained with Giemsa stain. One hundred cells from each slide were counted to determine phagocytosis. Percentage phagocytosis and phagocytic index were calculated (Verma et al., 2012).

\section{Estimation of immunoglobulin levels using sandwich ELISA}

Serum samples from all groups were diluted (1:3) in 50 $\mathrm{mM}$ carbonate buffer ( $\mathrm{pH}$ 9.6) and added to individual wells of immunoassay plates (Greiner Bio-one, UK) and incubated for $12-14 \mathrm{~h}$ at $4{ }^{\circ} \mathrm{C}$. Unbounded serum proteins were removed by 3 successive washings with wash buffer (PBS having 0.05\% Tween 20) at RT. The unbounded sites were blocked by adding $300 \mu \mathrm{l}$ of $1 \%$ casein (prepared in PBS) and incubated at $25^{\circ} \mathrm{C}$ for $2 \mathrm{~h}$. The wells were washed thrice with wash buffer; $300 \mu \mathrm{l}$ of sonicated $V$. harveyi solution $\left(1 \times 10^{5} \mathrm{cells} / \mathrm{ml}\right.$ in PBS) was added to each well of the plate and incubated for $2 \mathrm{~h}$ at RT. Wells were again washed with wash buffer. One hundred microliters of rat anti- $V$. harveyi Ig (1:1000 diluted in PBS-T; raised in Wistar rats) was added to the wells and incubated at $25^{\circ} \mathrm{C}$ for $2 \mathrm{~h}$. After 3 washings with wash buffer, HRPconjugated secondary antibody (rabbit anti-rat IgG; 1 : 1000 diluted in PBS-T) was added and incubated at $25^{\circ} \mathrm{C}$ for the next $90 \mathrm{~min}$. Unbounded antibodies were washed, and $125 \mu \mathrm{l}$ substrate solution $(0.05 \% \quad$ o-

Table 2 Antioxidant potential and total flavonoids in methanol and ethanol extracts of E. crassipes leaf powder through DPPH and FRAP assays

\begin{tabular}{llll}
\hline & DPPH assay (\% scavenging activity) & FRAP assay $\left(\mathbf{m M ~ F e} \mathbf{~}^{\mathbf{2}} / \mathbf{m g}\right.$ extract) & Total flavanoids $(\boldsymbol{\mu g}$ QEs $/ \mathbf{m g}$ extract) \\
\hline Methanol extract & $48.15 \pm 1.02^{\mathrm{b}}$ & $231.89 \pm 2.95^{\mathrm{b}}$ & $30.46 \pm 1.71^{\mathrm{a}}$ \\
Ethanol extract & $30.89 \pm 1.21^{\mathrm{a}}$ & $192.24 \pm 0.83^{\mathrm{a}}$ & $36.54 \pm 0.76^{\mathrm{b}}$ \\
Ascorbic acid & $92.66 \pm 1.02$ & $1428.28 \pm 146.20$ & -- \\
Gallic acid & $85.80 \pm 3.76$ & $2907.48 \pm 299.71$ & -- \\
\hline
\end{tabular}

Values are represented as mean \pm SEM. Antioxidant potential of methanol and ethanol extracts were compared by calculating $p$ values using $t$ test, and $p$ values less than 0.05 were considered significant. Dissimilar superscripts " $a$ " and " $b$ " in each assay represent that they are statistically different. Ascorbic acid and gallic acids were used as positive controls for DPPH and FRAP assays, respectively 
Table 3 Total phenols in methanol and ethanol extracts of $E$. crassipes. Amounts are represented in equivalence to other standard antioxidants containing phenolic group (except ascorbic acid)

\begin{tabular}{lll}
\hline $\boldsymbol{\mu g}$ equivalent/mg extract & Methanol extract & Ethanol extract \\
\hline Quercetin & $18.20 \pm 1.22^{\mathrm{a}}$ & $26.37 \pm 1.01^{\mathrm{b}}$ \\
Gallic acid & $16.75 \pm 1.08^{\mathrm{a}}$ & $24.06 \pm 0.90^{\mathrm{b}}$ \\
BHT & $60.12 \pm 1.25^{\mathrm{a}}$ & $78.82 \pm 2.53^{\mathrm{b}}$ \\
Ascorbic acid & $49.13 \pm 1.06^{\mathrm{a}}$ & $54.65 \pm 1.52^{\mathrm{b}}$ \\
\hline
\end{tabular}

Values are represented as mean \pm SEM. $p$ values less than 0.05 are considered statistically significant. Values having different superscripts "a" and " $b$ " in the same row are statistically different

phenylene-diamine-dihydrochloride in $0.1 \mathrm{M}$ citrate buffer, pH 5.0 containing $0.09 \% \mathrm{H}_{2} \mathrm{O}_{2}$ ) was added to each well. After $15 \mathrm{~min}, 35 \mu \mathrm{l}$ of $1 \mathrm{M}$ oxalic acid was added to stop reaction and absorbance was measured at $495 \mathrm{~nm}$ using ELISA plate reader (ECIL, India).

\section{Statistical analysis}

Experimental data was pooled, and statistical analysis was performed using ANOVA followed by NewmanKeuls' multiple range test. The values were represented as mean \pm standard error, and values with $p$ value 0.05 or less were considered statistically significant.

\section{Results}

Antibacterial activity of methanol and ethanol extracts from leaves of $E$. crassipes examined by disc diffusion assay showed inhibition on the growth of $V$. harveyi at different concentrations $(20,10$, and $5 \mathrm{mg} / \mathrm{ml})$. Ciprofloxacin used as positive control showed maximum inhibition, $V$. harveyi showed resistance against ampicillin, and no inhibition was observed in negative control (Table 1).

The antioxidant property of methanol and ethanol extracts, identified by percentage scavenging activity through DPPH assay and ferric-reducing ability, showed appreciable results in reference to standards. Methanol extract from the leaves of $E$. crassipes showed higher DPPH and FRAP assay values which suggest substantial antioxidant potential (Table 2).

Presence of total flavonoids and total phenols were detected in both the extracts. On estimation ethanol extract showed higher amount of total flavonoids (present in microgram of quercetin equivalents per milligram of extract; Table 2). Similarly, total phenol in ethanol extract of $E$. crassipes showed higher values in comparison to methanol extract (Table 3).

Gas chromatography mass spectrometric analysis (GCMS) showed presence of various components in the methanol extract of leaves from $E$. crassipes (Fig. 1). Palmitic acid (24.18\%), 9-hexadecenal (10.29\%), neophytadiene (8.42\%), 3-undecanone (7.36\%), stearic acid (6.35\%), vitamin E (5.85\%), stearic acid methyl ester (5.33\%), and stigmasterol (5.25\%) were the major compound constituents comprising more than $73 \%$ of the total compounds. Various studies have shown that these compounds exhibit antibacterial, antioxidant, anti-inflammatory, and immunostimulating properties (Table 4).

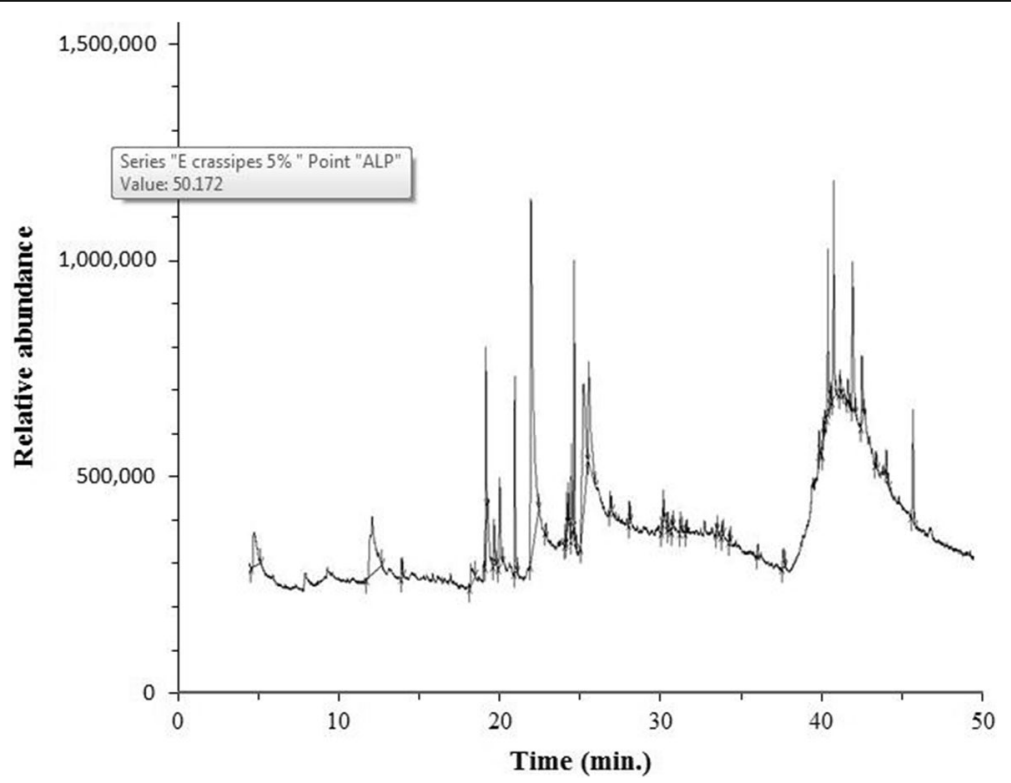

Fig. 1 GC chromatogram of methanol extract of E. crassipes (leaf) 
Table 4 Represents the compounds identified by gas chromatography mass spectrophotometry analysis of methanol extract of $E$. crassipes (leaf)

\begin{tabular}{|c|c|c|c|}
\hline Name & Retention time & Area\% & Chemical formula \\
\hline 4-Methyl-m-dioxane-(amine) & 4.626 & 3.04 & $\mathrm{C}_{5} \mathrm{H}_{10} \mathrm{O}_{2}$ \\
\hline 3-Undecanone & 12.013 & 7.36 & $\mathrm{C}_{11} \mathrm{H}_{22} \mathrm{O}$ \\
\hline 1-Hexadecene & 13.868 & 0.42 & $\mathrm{C}_{16} \mathrm{H}_{32}$ \\
\hline 1-Nonadecene & 18.179 & 1.04 & $\mathrm{C}_{19} \mathrm{H}_{38}$ \\
\hline Neophytadiene & 19.104 & 8.42 & $\mathrm{C}_{20} \mathrm{H}_{38}$ \\
\hline Methyl palmitate & 20.919 & 4.24 & $\mathrm{C}_{17} \mathrm{H}_{34} \mathrm{O}_{2}$ \\
\hline Palmitic acid & 21.921 & 24.18 & $\mathrm{C}_{16} \mathrm{H}_{32} \mathrm{O}_{2}$ \\
\hline Myristic acid, methyl ester & 22.822 & 0.15 & $\mathrm{C}_{15} \mathrm{H}_{30} \mathrm{O}_{2}$ \\
\hline Linoleic acid, methyl ester & 24.055 & 0.35 & $\mathrm{C}_{19} \mathrm{H}_{34} \mathrm{O}_{2}$ \\
\hline Oleic acid, methyl ester & 24.156 & 0.83 & $\mathrm{C}_{19} \mathrm{H}_{36} \mathrm{O}_{2}$ \\
\hline Phytol & 24.447 & 2.56 & $\mathrm{C}_{20} \mathrm{H}_{40} \mathrm{O}$ \\
\hline Stearic acid, methyl ester & 24.617 & 5.33 & $\mathrm{C}_{19} \mathrm{H}_{38} \mathrm{O}_{2}$ \\
\hline 9-Hexadecenal & 25.202 & 10.29 & $\mathrm{C}_{16} \mathrm{H}_{30} \mathrm{O}$ \\
\hline Stearic acid & 25.528 & 6.35 & $\mathrm{C}_{18} \mathrm{H}_{36} \mathrm{O}_{2}$ \\
\hline Palmitic acid ( $\beta$ )-monoglyceride & 26.868 & 0.72 & $\mathrm{C}_{19} \mathrm{H}_{38} \mathrm{O}_{4}$ \\
\hline Methyl palmoxirate & 30.092 & 0.07 & $\mathrm{C}_{18} \mathrm{H}_{34} \mathrm{O}_{3}$ \\
\hline Alpha.-monostearin & 30.182 & 0.89 & $\mathrm{C}_{21} \mathrm{H}_{42} \mathrm{O}_{4}$ \\
\hline Cyclocarbosilane & 30.461 & 0.4 & $\mathrm{C}_{3} \mathrm{H}_{12} \mathrm{Si}_{3}$ \\
\hline Eicosanoic acid, methyl ester & 31.244 & 0.42 & $\mathrm{C}_{21} \mathrm{H}_{42} \mathrm{O}_{2}$ \\
\hline Di-n-octyl phthalate & 31.606 & 0.25 & $\mathrm{C}_{24} \mathrm{H}_{38} \mathrm{O}_{4}$ \\
\hline Squalene & 36.052 & 0.22 & $\mathrm{C}_{30} \mathrm{H}_{50}$ \\
\hline 3-Bromocholest-5-ene & 37.666 & 0.57 & $\mathrm{C}_{27} \mathrm{H}_{45} \mathrm{Br}$ \\
\hline Stigmast-5-en-3-ol, oleate & 40.439 & 2.99 & $\mathrm{C}_{47} \mathrm{H}_{82} \mathrm{O}_{2}$ \\
\hline 22,23-Dibromostigmasterol acetate & 40.612 & 0.42 & $\mathrm{C}_{31} \mathrm{H}_{50} \mathrm{Br}_{2} \mathrm{O}_{2}$ \\
\hline Vitamin E & 40.798 & 5.85 & $\mathrm{C}_{29} \mathrm{H}_{50} \mathrm{O}_{2}$ \\
\hline Epicedrol & 41.196 & 0.5 & $\mathrm{C}_{15} \mathrm{H}_{26} \mathrm{O}$ \\
\hline Stigmasterol & 41.978 & 5.25 & $\mathrm{C}_{29} \mathrm{H}_{48} \mathrm{O}$ \\
\hline Stigmast-5-en-3-ol & 42.561 & 2.94 & $\mathrm{C}_{29} \mathrm{H}_{50} \mathrm{O}$ \\
\hline 4,22-Stigmastadiene-3-one & 43.427 & 0.36 & $\mathrm{C}_{29} \mathrm{H}_{46} \mathrm{O}$ \\
\hline Cholest-4-en-3-one & 44.095 & 0.58 & $\mathrm{C}_{27} \mathrm{H}_{44} \mathrm{O}$ \\
\hline 3,5-Di-tert-butylphenol & 45.758 & 2.98 & $\mathrm{C}_{14} \mathrm{H}_{22} \mathrm{O}$ \\
\hline
\end{tabular}

Non-significant changes were observed in AST, ALT, and ALP levels in serum among all groups of fish, after 15 days of initial feeding with respective feeds (Fig. 2).

Phagocytic activity as shown in Fig. 3 was calculated in macrophages isolated from the spleen and head kidney from all groups on the 21st day of the experiment. Significant changes were observed in the positive control as well as in the experimental groups (3 and 4), when challenged with $V$. harveyi in comparison to the negative control group. However, highest levels of percentage phagocytosis and phagocytic index was observed in the experimental groups fed on supplemented feed containing 5\% of E. crassipes leaf powder. The phagocytic index of spleen macrophages showed insignificant difference within the experimental groups (3 and 4) but showed significant difference with control groups (1 and 2).

The total serum protein showed increased levels in the positive control group (group 2) and experimental groups (groups 3 and 4) in comparison to the negative control group (group 1) at days 7, 14, and 21. The highest levels of total serum protein was observed in the experimental group fed on 5\% supplemented feed at all times during the study (Fig. 4).

Figure 5 depicts the immunoglobulin levels in the serum of all groups at different time intervals. No timedependent changes were observed in the negative 


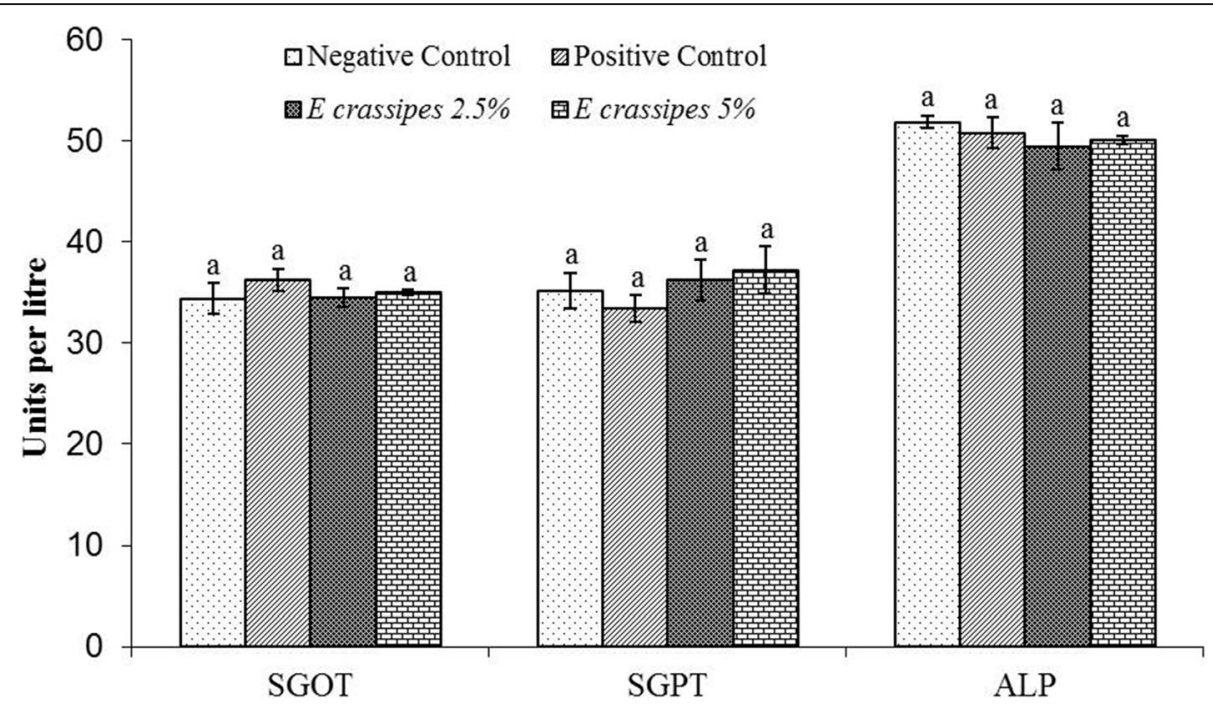

Fig. 2 AST, ALT, and ALP levels in the serum of various groups of Channa punctata: negative control, positive control, and experimental groups (2.5 and $5 \%$ feed, respectively). Values are expressed in mean \pm SEM. $p$ value was calculated by Student $t$ test $(p \leq 0.05)$. Error bars with superscript "a" represents that there was no statistical difference in levels among various groups

control group. However, significant differences were observed in the immunoglobulin levels in the positive control as well as in the experimental groups (groups 3 and 4). The highest levels of immunoglobulins were observed in group 4 fed on $5 \%$ E. crassipes supplemented feed.

\section{Discussion}

Synthetic vaccines and antibodies are being used for the prevention of disease in the aquaculture sector. The use of vaccines and antibodies are laborious, expensive, and specific for particular host and pathogen and may lead to compromised immune system of fish. The use of antibiotics in aquaculture has also increased but this may also lead to the emergence of antibiotic resistance against bacteria (Mishra, Oviedo-Orta, Prachi, Rappuoli, \& Bagnoli, 2012) and could yield fish with lower nutritional value, less biomass, and bio-accumulation of drugs or harmful chemicals (Mishra et al., 2012). This causes huge economic losses due to consumer refusal and hence less commercial value. This has urged aquaculturists and sensitized them toward the health of aquatic organisms. There is a realization to discover some more potential, herbal immunostimulants to minimize the stress due to various pathogens without any harmful effects.

Various studies have reported extracts from plants to exhibit antibacterial activity against various grampositive and gram-negative bacteria (Bartfay, Bartfay, \& Johnson, 2012; Marasini et al., 2015; Mariri \& Safi, 2014). Many of these extracts have equivalent or better antibacterial activity than standard antibiotics. Fish pathogenic bacteria like $V$. harveyi may causes severe damage in the liver, the kidney, and appendage degradation, suppressing the immune system in fish (Hashem \& El-barbary, 2013). V. harveyi showed ampicillin resistance; however, E. crassipes extract showed a zone of inhibition at different concentrations. Shanab, Shalaby, Lightfoot, and El-Shemy (2010) showed that methanol extract was more effective in comparison to ethanol extract and also reported the antimicrobial (antibacterial and anti-fungal) activity of crude extract of $E$. crassipes against various other bacteria.

Stress-related diseases in organisms are known to cause damage to different organs and may ultimately lead to death. Stress causes the release of oxygen free radicals. In order to minimize this, there is a need of antioxidants which help reduce free radicals. DPPH and FRAP assays showed the presence of antioxidant compounds. Methanol extract showed higher value in comparison to ethanol extract in both assays (Table 3 ).

The amount of total flavonoids and phenol present in the extracts were also evaluated in the reference with other phenolic compounds or phenol-derived compounds. Tables 3 and 4 suggest that there were high amounts of flavonoids and phenolic compounds in the ethanol extract. Literature review suggests that phenols, flavonoids, tannin, terpenes, and other important compounds are present as secondary metabolites in plants (Thomas \& Krishnakumari, 2015; Toure, Bouatia, Idrissi, \& Draoui, 2015). These compounds inhibit reactive oxygen species and free radicals, prevent mutations, and have antibacterial, anti-viral, antioxidant, anti-inflammatory, and anticancer as well as cardio-protective activities. 


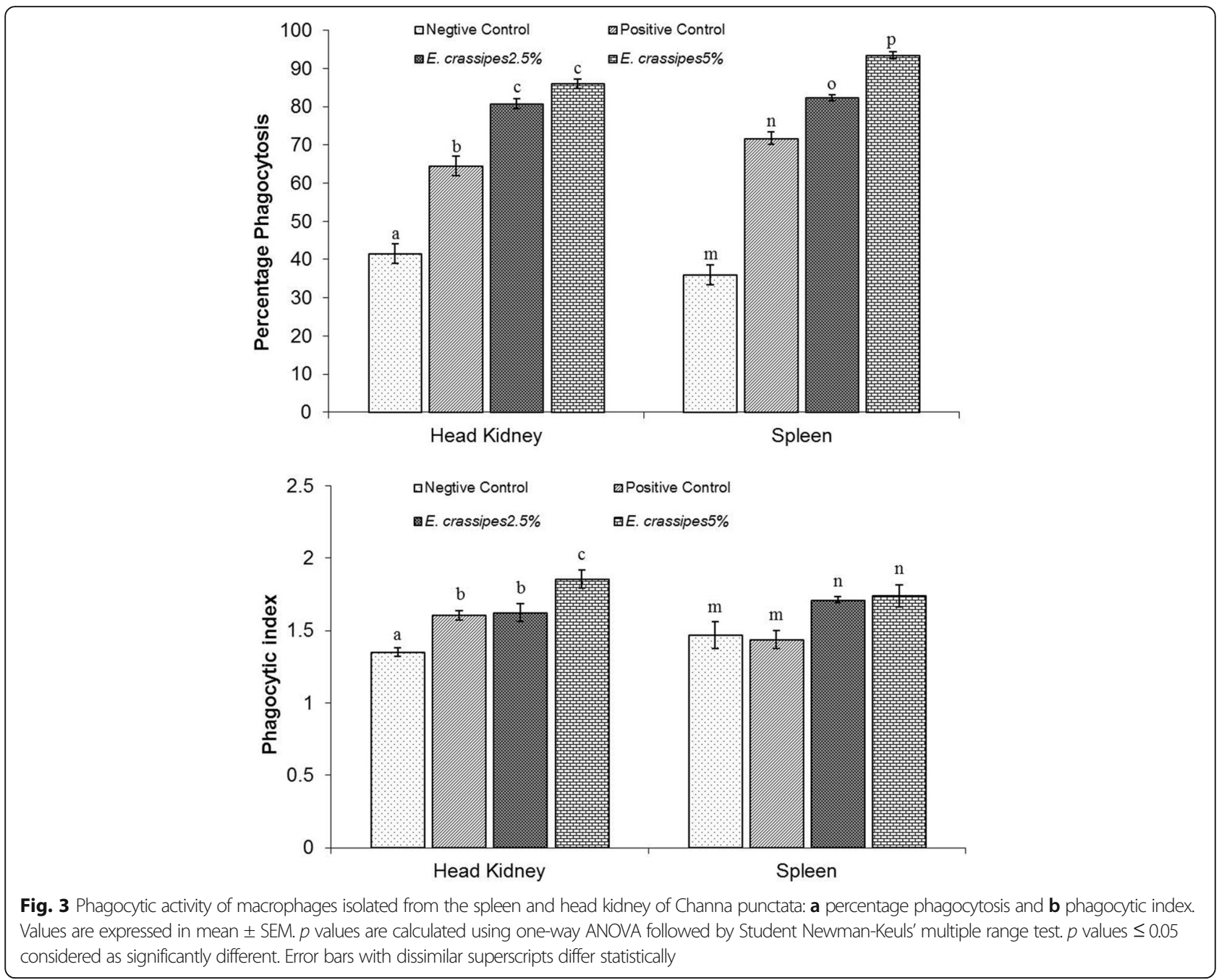

E. crassipes on GC-MS analysis showed the presence of many secondary metabolites which have capabilities like antibacterial and anti-viral properties, including protection against many diseases: anti-tumor, anti-cancer, neuroprotective, allergenic, oxidative stress inhibitor, NO-inhibitor, and cardio-protective (Hassan et al., 2011; Somasagara et al., 2012; Valenzuela, Imarai, Torres, \& Modak, 2013).

Early investigations revealed the presence of harmful metabolites and chemicals in plants that cause adverse effects on the health of the organism (Ardo et al., 2008; Lavecchia, Rea, Antonacci, \& Giardi, 2013). Enzyme-based liver function test (ALT and AST) and alkaline phosphatase levels were checked to identify if there were any detrimental effects of E. crassipes in Channa punctata. The tests revealed that there were no significant changes in the test samples of the fish fed on supplementary feed (Fig. 2).

In the present study, macrophages isolated from the spleen and head kidney showed significant increase in phagocytosis (percentage phagocytosis and phagocytic index) in the experimental groups when compared with the control groups. This suggested enhanced cellmediated immune response in fish (El-Boshy et al., 2014; Sirimanapong et al., 2015; Verma, Rani, Sehgal, \& Prakash, 2013).

Antibodies form the major component of the humoral immune system, and they have been well documented to play an adaptive role in neutralizing and destroying the invading pathogens in all class of organisms, including fish. Increase in the titer of these specific antibodies helps in neutralization and speedy removal of antigen introduced in the host body. The fish challenged with $V$. harveyi showed enhanced antibody titer in a time-dependent manner. Higher levels of antibodies observed in the experimental groups showed an immunomodulatory activity of plant when introduced in fish feed (Verma et al., 2015). 


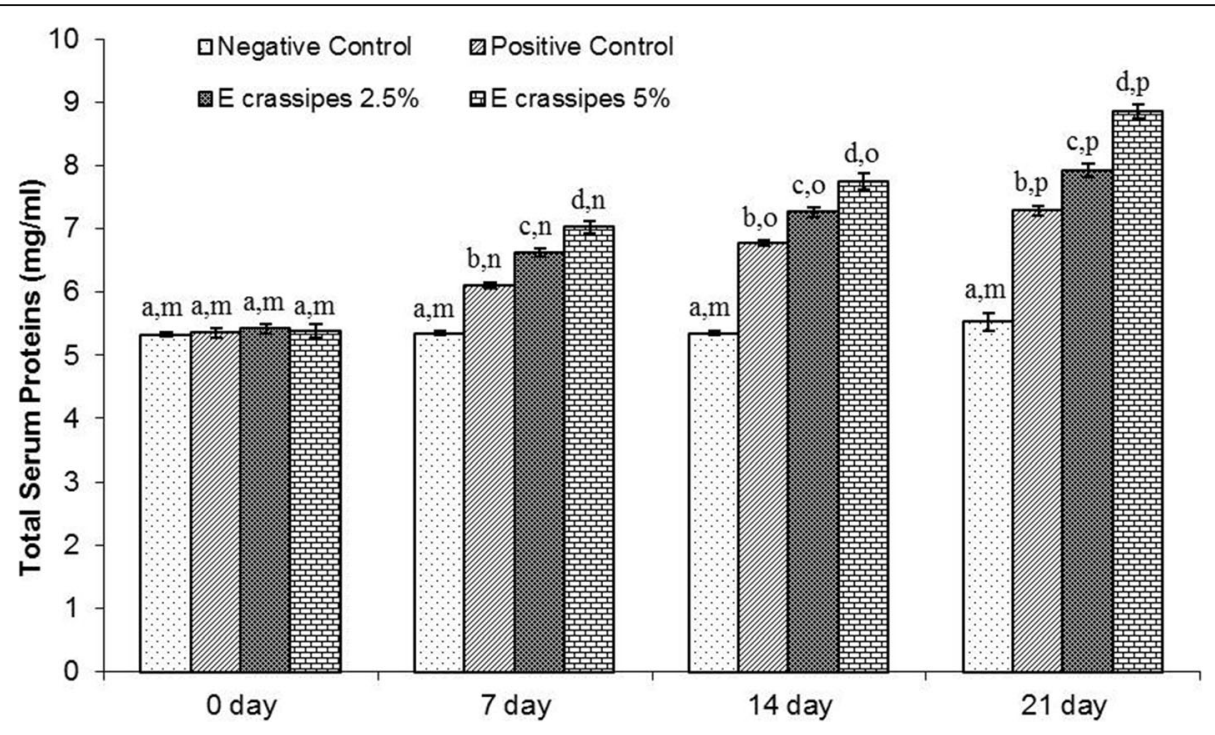

Fig. 4 Total serum proteins in serum samples of various groups of C. punctata on days $0,7,14$, and 21. Values are expressed in mean \pm SEM. $p$ values were calculated using one-way ANOVA followed by Student Newman-Keuls' multiple range test, and $p$ values $\leq 0.05$ are statistically different. Error bars with dissimilar superscripts differ significantly. Values compared within four groups, specific time point is represented by superscripts "a" to "d," and within groups at various time points is represented by superscripts " $m$ " to " $p$ "

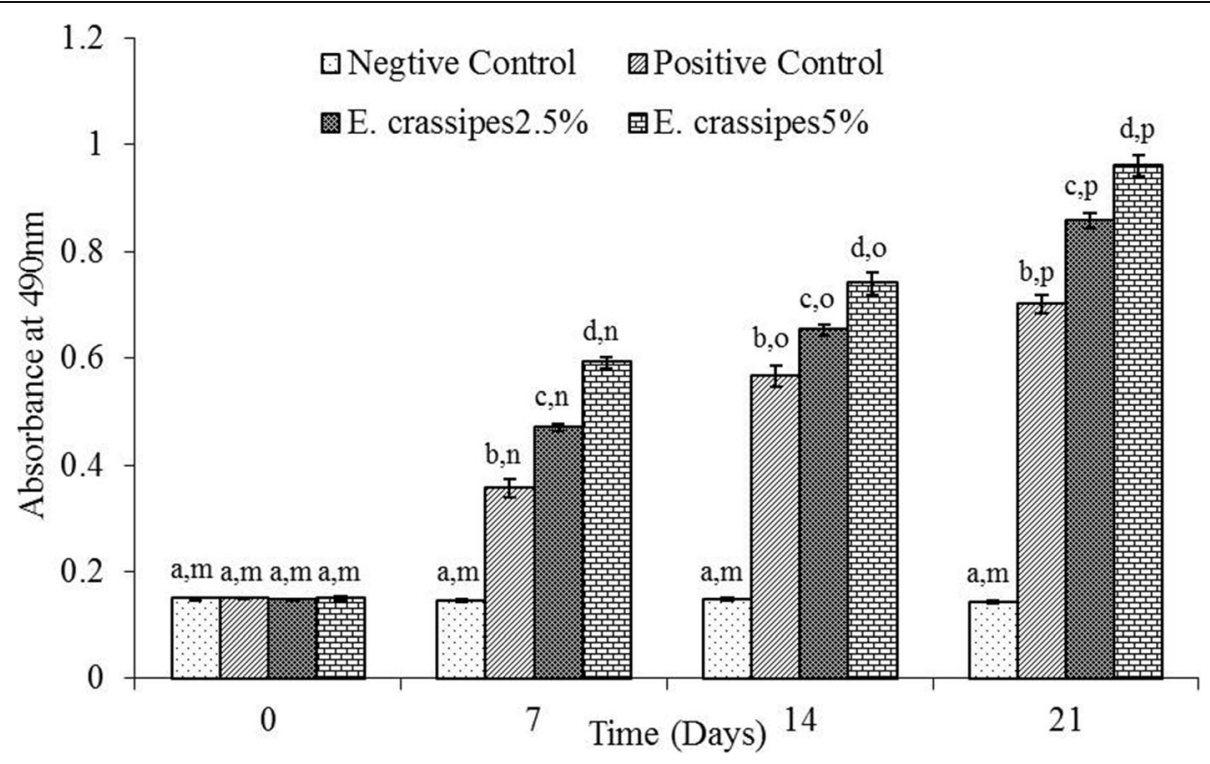

Fig. 5 Immunoglobulin levels in the serum of $C$. punctata at various time intervals (days $0,7,14$, and 21). Values are expressed in mean \pm SEM. $p$ values were calculated using one-way ANOVA followed by Student Newman-Keuls' multiple range test, and $p$ values $\leq 0.05$ are statistically different. Error bars with dissimilar superscripts differ significantly. Values compared within four groups, specific time point is represented by superscripts "a" to "d," and within groups at various time points is represented by superscripts " $m$ " to " $p$ " 


\section{Conclusion}

E. crassipes is a fast-growing weed plant which is easily available and did not had any detrimental effect on fish when supplemented in its feed. It also stimulated both humoral and cell-mediated immune response in Channa punctata. Therefore, we recommend field trials of feed supplemented with E. crassipes so that it can be recommended for development of disease resistance in $C$. punctata against $V$. harveyi.

\section{Abbreviations}

E. crassipes: Eichhornia crassipes; C. punctata: Channa punctata; V. harveyi: Vibrio harveyi; GC-MS: Gas chromatography mass spectrometry; DDA: Disc diffusion assay; DMSO: Dimethyl sulphoxide; DPPH: 2,2-Diphenyl-1picrylhydrazyl; FRAP: Ferric-reducing ability of plasma; TPTZ: 2,4,6-Tripyridyl-striazine; PBS: Phosphate buffer saline

\section{Acknowledgements}

The authors are thankful to Mr. Ajay Kumar (AIRF-JNU) for conducting the GC-MS and its analysis. The authors are thankful to the technical staff at Sri Venkateswara College and Department of Zoology, University of Delhi, New Delhi.

\section{Authors' contributions}

VKV, OP, and SRK designed the experimental work and performed experimentation, KVR wrote the manuscript and NS supervised the whole experiment. All authors discussed the result and read and approved the final manuscript.

\section{Funding}

This work was not funded by any national or international agencies.

\section{Availability of data and materials}

The raw files for GC-MS and other parameters can be available by the corresponding author on request.

\section{Ethics approval and consent to participate}

The experimentation on Channa punctata fish was approved by the Animal Ethics Committee, University of Delhi. Investigations were performed following INSA, New Delhi Guidelines.

\section{Consent for publication}

Not required.

\section{Competing interests}

The authors declare that they have no competing interest.

\section{Author details}

${ }^{1}$ Department of Pharmacology, All India Institute of Medical Sciences, New Delhi 110029, India. '2Department of Zoology, Sri Venkateswara College, University of Delhi, Dhaula Kuan, New Delhi 110021, India. ${ }^{3}$ Department of Zoology, University of Delhi, Delhi 110007, India. ${ }^{4}$ Department of Zoology, Kalindi College, University of Delhi, East Patel Nagar, New Delhi 110008, India.

Received: 20 May 2020 Accepted: 16 December 2020

Published online: 07 January 2021

\section{References}

Ardo, L., Yin, G., Xu, P., Varadi, L., Szigeti, G., Jeney, Z., \& Jeney, G. (2008). Chinese herbs (Astragalus membranaceus) and (Lonicera japonica) and boron enhances the non-specific immune response of Nile tilapia (Oreochromis niloticus) and resistance against Aeromonas hydrophila. Aquaculture, 275, 26-33.

Arvouet-Grand, A., Vennat, B., Pourrat, A., \& Legret, P. (1994). Standardization of a propolis extract and identification of the main constituents. Journal de Pharmacie de Belgique, 49, 462-468.

Bartfay, W. J., Bartfay, E., \& Johnson, J. G. (2012). Gram-negative and gram-positive antibacterial properties of whole plant extract of willow herb (Epilibium angustifolium). Biological Research for Nursing, 14, 85-89.
Bergier, I., Salis, S. M., Miranda, C. H. B., Ortega, E., \& Luengo, C. A. (2012). Biofuel production from water hyacinth in the pantanal wetland. Ecohydrology \& Hydrobiology, 12, 77-84.

Brand-Williams, W., Cuvelier, M. E., \& Berset, C. (1995). Use of free radical method to evaluate antioxidant activity. LWT-Food Science and Technology, 28, 25-30.

Cabello, F. C. (2006). Heavy use of prophylactic antibiotics in aquaculture: A growing problem for human and animal health and for the environment. Environmental Microbiology, 8, 1137-1144.

Chatterjee, S., \& Haldar, S. (2012). Vibrio related diseases in aquaculture and development of rapid and accurate identification methods. Journal of Marine Science Research and Development, S1, 002.

Djeridane, A., Yousfi, M., Nadjemi, B., Boutassouna, D., Stocker, P., \& Vidal, N. (2006). Antioxidant activity of some Algerian medicinal plants extracts containing phenolic compounds. Food Chemistry, 97, 654-660.

El-Boshy, M., El-Ashram, A., Risha, E., Abdelhamid, F., Zahran, E., \& Gab-Alla, A. (2014). Dietary fucoidan enhance the non-specific immune response and disease resistance in African catfish Clarias gariepinus, immunosuppressed by cadmium chloride. Veterinary Immunology and Immunopathology, 162, 168-173.

Gewali, M. B. (2008). Aspects of traditional Medicine in Nepal. Japan: Institute of Natural Medicine, University of Toyama.

Hashem, M., \& El-barbary, M. (2013). Vibrio harveyi infection in Arabian surgeon fish (Acanthurus sohal) of red sea at Hurghada, Egypt. The Egyptian Journal of Aquatic Research, 39, 199-203.

Hassan, S. W., Abubakar, M. G., Umar, R. A., Yakubu, A. S., Maishanu, H. M., \& Ayeni, G. (2011). Pharmacological and toxicological properties of leaf extracts of Kingelia africana (bignoniaceae). Journal of Pharmacology and Toxicology, 6, 124-132.

Hoareau, L., \& DaSilva, E. J. (1992). Medicinal plants: A re-emerging health aid. Electronic Journal of Biotechnology, 2(2), 3-4.

Huang, W. (2015). An integrated biomass production and conversion process for sustainable energy. Sustainability, 7, 522-536.

Lalitha, P., Sripathi, S. K., \& Jayanthi, P. (2012). Secondary metabolites of Eichhornia crassipes (Water hyacinth): A review (1949-2011). Natural Product Communications, 7, 1249-1256.

Lavecchia, T., Rea, G., Antonacci, A., \& Giardi, M. T. (2013). Healthy and adverse effect of plant-derived functional metabolites: The need of revealing their content and bioactivity in a complex food matrix. Critical Reviews in Food Science and Nutrition, 53, 198-213.

Lowry, O. H., Rosebrough, N. J., Farr, A. L., \& Randall, R. J. (1951). Protein measurement with the folin phenol reagent. Journal of Biological Chemistry, 193, 265-275.

Marasini, B. P., Baral, P., Aryal, P., Ghimire, K. R., Neupane, S., Dahal, N., ... Shrestha, K. (2015). Evaluation of antibacterial activity of some traditionally used medicinal plants against human pathogenic bacteria. BioMed Research International, 2015, 265425.

Mariri, A. A., \& Safi, M. (2014). In vitro antibacterial activity of several plant extracts and oils against some gram-negative bacteria. Iranian Journal of Medical Sciences, 39, 36-43.

McVea, C., \& Boyd, C. (1975). Effects of water hyacinth cover on water chemistry, phytoplankton, and fish in ponds. Journal of Environmental Quality, 4, 375-378.

Meena, A. K., Bansal, P., \& Kumar, S. (2009). Plants-herbal wealth as a potential source of Ayurvedic drugs. Asian Journal of Traditional Medicines, 4, 152-170.

Miliauskas, G., Venskutonis, P. R., \& Van Beek, T. A. (2004). Screening of radical scavenging activity of some medicinal plants and aromatic plant extract. Food Chemistry, 85, 231-237.

Mishra, R. P., Oviedo-Orta, E., Prachi, P., Rappuoli, R., \& Bagnoli, F. (2012). Vaccines and antibiotic resistance. Current Opinion in Microbiology, 15, 596-602.

Rodgers, C. J., \& Furones, M. D. (2009). Antimicrobial agents in aquaculture: Practice, need and issues. In C. Roger, \& B. Basurco (Eds.), The use of veterinary drugs and vaccines in Mediterranean aquaculture, (pp. 41-59). Zaragoza: CIHEAM.

Samanidou, V. F., \& Evaggelopoulou, E. N. (2007). Analytical strategies to determine antibiotic residues in fish. Journal of Separation Science, 30, 2549-2569.

Sarikurkcu, C., Ozer, M. S., Cakir, A., Eskici, M., \& Mete, E. (2013). GC/MS evaluation and in vitro antioxidant activity of essential oil and solvent extracts of an endemic plant used as folk remedy in Turkey: Phlomis bourgaei Boiss. Evidence-Based Complementary and Alternative Medicine, 2013, 1-7.

Shanab, S. M. M., Shalaby, E. A., Lightfoot, D. A., \& El-Shemy, H. A. (2010). Allopathic effect of water hyacinth (Eichhornia crassipes). PLoS One, 5, e13200. Sirimanapong, W., Adams, A., Ooi, E. L., Green, D. M., Nguyen, D. K., Browdy, C. L., .. Thompson, K. D. (2015). The effect of feeding immunostimulant $\beta$-glucan 
on the immune response of Pangasianodon hypophthalmus. Fish \& Shellfish Immunology, 45, 357-366.

Somasagara, R. R., Hegde, M., Chiruvella, K. K., Musini, A., Choudhary, B., \& Raghavan, S. C. (2012). Extracts of strawberry fruits induced intrinsic pathway of apoptosis in breast cancer cells and inhibits tumor progression in mice. PLoS One, 7, e47021.

Thomas, R. A., \& Krishnakumari, S. (2015). Phytochemical quantification of primary and secondary metabolites of Myristica fragrans ( $\mathrm{H}$.) ethanolic seed extract. International Journal of Pharma and Bio Sciences, 6, 1046-1053.

Tidwell, J. H., \& Allan, G. L. (2001). Fish as food: Aquaculture's contribution. EMBO Reports, 2, 958-963.

Todd, J., \& Josephson, B. (1996). The design of living technologies for waste treatment. Ecological Engineering, 6, 109-136.

Toure, H. A., Bouatia, M., Idrissi, M. O. B., \& Draoui, M. (2015). Phytochemical screening and antioxidant activity of aqueous-ethanolic extracts of Opuntia ficus indica. Journal of Chemical and Pharmaceutical Research, 7, 409-415.

Valenzuela, B., Imarai, M., Torres, R., \& Modak, B. (2013). Immunomodulatory effects of the aromatic geranyl derivative filifolinone tested by the induction of cytokine expression. Developmental \& Comparative Immunology, 41, 675-682.

Verma, V. K., Rani, K. V., Sehgal, N., \& Prakash, O. (2012). Immunostimulatory response induced by supplementation of Ficus benghalensis root powder, in the artificial feed the Indian freshwater murrel, Channa punctata. Fish \& Shellfish Immunology, 33, 590-596.

Verma, V. K., Rani, K. V., Sehgal, N., \& Prakash, O. (2013). Immunostimulatory effect of artificial feed supplemented with indigenous plants on Clarias gariepinus against Aeromonas hydrophila. Fish \& Shellfish Immunology, 35, 924-931.

Verma, V. K., Rani, K. V., Sehgal, N., \& Prakash, O. (2015). Enhanced disease resistance in the Indian snakehead, Channa punctata against Aeromonas hydrophila, through $5 \%$ feed supplementation with F. benghalensis (aerial root) and $L$. leucocephala (pod seed). Aquaculture International, 23, 1127-1140.

Zhou, J., Fang, W., Yang, S., Yang, X., Zhou, S., Hu, L., ... Xie, L. (2012). A nonluminescent and highly virulent Vibrio harveyi strain is associated with "Bacterial White Tail Disease" of Litopenaeus vannamei Shrimp. PLoS One, 7(2), e29961.

\section{Publisher's Note}

Springer Nature remains neutral with regard to jurisdictional claims in published maps and institutional affiliations.

\section{Submit your manuscript to a SpringerOpen ${ }^{\circ}$ journal and benefit from:}

- Convenient online submission

- Rigorous peer review

- Open access: articles freely available online

- High visibility within the field

- Retaining the copyright to your article

Submit your next manuscript at $\boldsymbol{\nabla}$ springeropen.com 